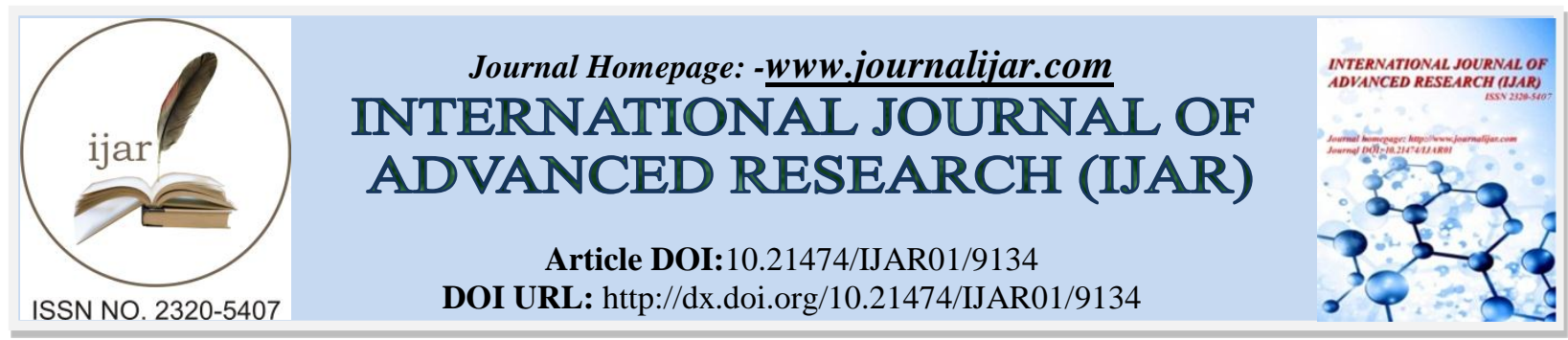

RESEARCH ARTICLE

\title{
ANALYSIS EFFECT OF 7P MARKETING MIX ON CONSUMER PURCHASE DECISIONS CASE STUDY IN BRITANIA EDUCATIONAL INSTITUTIONS.
}

Suryaningsih, Cepi Pahlevi And Mursalim Nohong. Batua Raya XIV Manggala Districk Makassar City South Sulawesi 90233 Indonesia.

\section{Manuscript Info}

Manuscript History

Received: 24 March 2019

Final Accepted: 26 April 2019

Published: May 2019

Key words:-

marketing, 7p marketing mix, consumer purchasing decision

\section{Abstract}

Background: effect of $7 \mathrm{p}$ marketing mix on consumer purchase decisions in case of course place or educational institutions

Aim and Objective: to determine the effect of $7 \mathrm{p}$ marketing mix on consumer purchase decisions

Methodology: this study uses a quantitative approach that intends to explain the position of the variables studied and the relationship between one variable with another variable. This research is intended to test hypotheses that have been formulated previously. This study will explain the causal relationship between variables through hypothesis testing. In this study, the analytical method used is a simple regression analysis using the SPSS program.

Result: the six variables such product, price, place, promotion, people, physical evidence have a positive and significant effect on consumer purchasing decisions, process has a positive and insignificant effect on consumer purchasing decisions.

Conclusion: the institutions must improve their program and take a new challenge to get more customer or student

Copy Right, IJAR, 2019,. All rights reserved.

\section{Introduction:-}

Institutions of education or tutoring are one of the educational institutions under private processing that are engaged in capacity building services and development as well as places for student learning. With the growing development of current tutoring services. The existence of the service industry gets its own place among the community, especially parents which their children are students. Indirectly these conditions can increase competition among similar educational institutions in terms of offering the best products to meet consumer needs. In general, consumers are students who want to get the maximum and satisfying service from service units for tutoring students, both from the aspect of administrative services, aspects of teaching education services, as well as from the aspect of service provided by tutoring facilities. One aspect that reflects customer satisfaction is the number of students who take the tutoring program.

Viewed in terms of business management, managers of tutoring services as well as most business ventures in other fields, also carry out efforts to increase the number of students from time to time, among others by conducting a Marketing Mix, which is generally a a series of marketing variables that must be mastered by service companies, which are used to achieve goals in the target market. The traditional marketing mix concept (traditional marketing mix) consists of 4P, they are product, price, place and promotion, while for service marketing (the service marketing

Corresponding Author:-Suryaningsih.

Address:-Batua Raya XIV Manggala Districk Makassar City South Sulawesi 90233 Indonesia. 
mix) there are additional 3P, namely people (person), physical evidence (physical evidence) and process (service process). Every company must be able to manage and choose which marketing mix elements are prioritized so that it can effectively influence consumer decisions to buy products or services that are marketed. One of the educational institutions in Makassar City is the Britania Educational Institution, better known as Bitania School of English, which was officially established on October 4, 2002, which is oriented towards English language courses.

\section{Materials and Methods:-}

A prospective study was conducted in Britania educational institutions in Makassar South Sulawesi with 54 respondence.

\section{Statistical Analysis}

This study using analytical method a simple regression analysis using SPSS program for windows.

\section{Results and discussions:-}

After processing data on 54 respondents' data, the results of the research show that the six variables, namely product, price, place, promotion, people and physical evidence, having positive and significant results and process variables have a positive but not significant effect. The most influential variable is the promotion variable, where in the Britania education institution promotion is done more effectively to increase the number of students, this is done by promoting both directly to consumers / students and indirectly. Promotion is carried out more towards WOM or word of mouth.

In this study, the researchers used the SPSS 22 for Windows software application program that aimed to simplify and obtain the right calculation accuracy and for data processing, namely testing the model, finding the coefficient value of each variable and testing the hypothesis of the influence of the $7 \mathrm{p}$ marketing mix on consumer purchasing decisions. The tables below show as the result of analysis data using tools SPSS program.

Table I:-Results of data processing

\begin{tabular}{|c|c|c|c|c|c|c|}
\hline \multicolumn{7}{|c|}{ Coefficients $\mathrm{s}^{\mathrm{a}}$} \\
\hline \multicolumn{2}{|c|}{ Model } & \multicolumn{2}{|c|}{ Unstandardized Coefficients } & $\begin{array}{l}\text { Standardized } \\
\text { Coefficients } \\
\text { Beta }\end{array}$ & $\mathrm{t}$ & Sig. \\
\hline \multirow[t]{11}{*}{1} & (Constant) & 4.399 & 3.722 & & 1.182 & .020 \\
\hline & Produk & 10.33 & .138 & .491 & 0.345 & 0.039 \\
\hline & Price & 8.571 & .140 & .374 & 0.215 & .012 \\
\hline & Place & 7.980 & .142 & .354 & 0.534 & .030 \\
\hline & Promotion & 12.8 & .133 & .292 & 0.665 & .009 \\
\hline & People & 8.444 & .145 & .535 & 0.332 & .034 \\
\hline & Process & 4.100 & .130 & .383 & 0.321 & .446 \\
\hline & Physical & 5.913 & .140 & .334 & 0.114 & .040 \\
\hline & R-Squared & $=0.77$ & $\begin{array}{l}\text { Adjusted } \\
\text { Squared }\end{array}$ & $=0.78$ & $\mathrm{~N}=54$ & $\mathrm{Df}=47$ \\
\hline & F-Statistik & $=0.358$ & $\begin{array}{l}\text { Prob(F- } \\
\text { Statistik) }\end{array}$ & $=0.037$ & thitung & $=1.182$ \\
\hline & fhitung & $=0.358$ & ftabel & $=0.124$ & ttabel & $=0.981$ \\
\hline \multicolumn{7}{|c|}{ Durbin - Watson $=2.173$} \\
\hline \multicolumn{7}{|c|}{ Ket. Signifikan pada $\alpha=5 \%$} \\
\hline \multicolumn{7}{|c|}{ a. Dependent Variable: consumer purchasing decisions } \\
\hline
\end{tabular}

Based on the regression testing table above, the regression equation is obtained as follows: $\mathrm{Y}=4.399+10.33 \mathrm{X} \_1+8.571 \mathrm{X} \_2+7.980 \mathrm{X} \_3+12.8 \mathrm{X} \_4+8.444$ X_5 + 4.1 X_6 + 5.913X_7 
The interpretation of the regression on the results of data processing table I above is as follows: Constant (a)

This means that if all independent variables have a value of zero (0), the value of the dependent variable (Beta) is 4,399 .

Effect of product variables (X1) on consumer purchasing decisions (Y)

The first test carried out was the effect of product variables (X1) on consumer purchasing decision variables (Y), a summary of the results of regression analysis using SPSS in this study can be seen in the summary of the regression results above. Based on the summary regression analysis above, it is known that product / product variables have a positive and significant effect on consumer purchasing decisions, this can be seen from the coefficient of $(\beta)=10.33$ and because it obtained a significant value of 0.039 which means smaller than $\alpha=0.05$. This means that every increase in product variable / product one unit then the decision variable to choose consumers (Y) will increase by 10.33 assuming that the other independent variables from the regression model are fixed.

Effect of price variable (X2) on consumer purchasing decisions (Y)

The second test conducted is the effect of price variable (X2) to the consumer purchasing decision variable (Y). Based on the summary regression analysis above, it is known that the price variable has a positive and significant effect on the variables of consumer purchasing decisions, this can be seen from the regression coefficient of $\beta=$ 8.531 and because it obtained a significant value of 0.012 which means smaller than $\alpha=0.05$. This implies that every increase in the price variable / price of one unit then the decision variable choosing the consumer (Y) will increase by 6.66 assuming that the other independent variables from the regression model are fixed.

\section{Effect of place variable (X3) on consumer purchasing decisions (Y)}

The third test conducted is the effect of place variable (X3) on consumer purchasing decisions (Y). Based on the summary regression analysis above, it is known that place / place variables have a positive and significant effect on consumer purchasing decision variables, this can be seen from the regression coefficient of $\beta=7.980$ and because it obtained a significant value of $=0.03$ which means smaller than $\alpha=0.05$. This implies that every increase in place variable / place of one unit, the decision variable choosing consumer (Y) will increase by 7.980 assuming that the other independent variables of the regression model are fixed.

\section{Effect of promotion variable (X4) on consumer purchasing decisions ( $\mathbf{Y})$}

The fourth test conducted is the effect of promotion variable (X4) on consumer purchasing decisions (Y). Based on the summary regression analysis above, it is known that the Promotion variable has a positive and significant effect on the variable consumer purchasing decisions of $\beta=12.8$ and because it obtained a significant value of 0.00 which means smaller than $\alpha=0.05$. This means that every increase in the variable promotion / promotion of one unit then the decision variable choosing the consumer (Y) will increase by 12.8 assuming that the other independent variables of the regression model are fixed.

\section{Effect of people (X5) variables on consumer purchasing decisions (Y)}

The fifth test conducted is the influence of the people variable (X5) on consumer purchasing decisions (Y). Based on the summary regression analysis above, it is known that the people variable has a positive and significant effect on the variable consumer purchasing decisions, this can be seen from the regression coefficient of $\beta=8.444$ and because it obtained a significant value of 0.034 which means smaller than $\alpha=0.05$. This implies that each increase in one unit of person variable then the decision variable choosing consumer (Y) will increase by 8,444 assuming that the other independent variables of the regression model are fixed.

\section{Effect of process / process variables (X6) on consumer purchasing decisions (Y)}

The sixth test conducted is the effect of process variables (X6) on consumer purchasing decisions (Y) using SPSS in this study can be seen in the summary of the regression results above. Based on the summary regression analysis above, it is known that the process variable does not significantly influence the consumer purchasing decision variables, this can be seen from the regression coefficient of $\beta 4.100$ and because it obtained a significant value of 0.446 which means greater than $\alpha=0.05$. This means that every increase in a unit process variable, the decision variable for choosing consumers (Y) will increase by 4,100 assuming that the other independent variables of the regression model are fixed. 


\section{Effect of physical physical evidence (X7) variables to consumer purchasing decisions (Y)}

The last test conducted is the influence of Pyhsical Evidence (X7) variable on consumer purchasing decisions (Y). Based on the summary of the regression analysis above, it is known that the physical evidence variable has a positive and significant effect on the variables of consumer purchasing decisions of $\beta 5,913$ and because a significant value of 0.040 is obtained which means smaller than $\alpha=0.05$. This implies that each increase in a unit physical evidence variable then the decision variable to choose consumers (Y) will increase by 5,913 assuming that the other independent variables of the regression model are fixed.

Of the seven variables that become benchmarks in this study, 6 variables have a positive and significant effect and one variable that has a positive but not significant effect on consumer purchasing decisions in the british educational institution. The most influential variable is the promotion variable. The results of this study are indicated by the value of tcount $=1.182$ and the value of $t$ table with a significance level of $5 \%$ on degrees of freedom $(\mathrm{df})=47$ is 0.124 , so that tcount> $t$ table $(1.182>0.124)$. If there is an increase of each variable by 1 percent, it will affect consumer purchasing decisions in the British Educational Institution (Y) by 1 percent (cateris paribus).

\section{Limitation of the study}

For further research, it is expected for the reasearchers to be able to add more variables other than marketing mix factors that influence purchasing decisions. In addition, further researchers can add research samples and use different analytical tools so that the results of this study can be further developed.

\section{Conclusion:-}

Based on variables that predominantly influence that is promotion, to the British educational institutions to continue to increase the promotion carried out to attract new prospective customers. Because promotion through word of mouth is still not fast enough to attract customers and conduct other sales promotions through discounts or lottery prizes. For British education institutions to continue to provide the best service and pay attention to the processes within the institution. As well as improving the quality of facilities and the comfort of learning for existing student participants so as to make customers in this case the students feel at home and last for a long time in participating in tutoring.

\section{References:-}

1. Bulley, Cynthia A, 2014. International Journal of Economics, Commerce and Management, United Kingdom "The strategic marketing in education services for the case of a private tertiary institution in Ghana. Vol. II, Issue 6

2. Dally, Dadang. 2010. Balanced Scorecard; An Approach in School-Based Management Implementation. Bandung, Rosda.

3. Dedik, 2014, "The Marketing Strategy of Educational Services in Increasing Interest in Educational Services at the Muallimim Muhammadiyah Madrasah in Yogjakarta", Thesis, Islamic Education Management and Policy Study Program at Islan Alauddin University, Sunan Kalijaga.

4. Fortiana, Dewi, 2016, "Study of Strategic Management Based on Balance Scorecard at AL-Kautsar Lampung Foundation", Thesis, Lampung University Management Masters Program.

5. Handoko, Tanoto, 2002, "Formulation of Repsol Lubricants Marketing Strategy at PT. Sukabumi Trading Coy Jateng ", Thesis, Master of Management Program at Diponegoro University.

6. Harper, Orvile C. Walker, Jean Claude Larreche, 2000, "Marketing Management: A Strategic Approach with Global Orientation", Jakarta: Erlangga

7. Jain, C. S, 1990, Marketing Planning and Strategy, Boston 3td edition, South Western Publishing Coy.

8. Jelena Gajić, 2012. Importance of marketing in higher education institutions. Singidunum University, Department for Tourism and Hospitality Management, 32, Belgrade, Serbia.

9. Kotler, Philip, 2000, "Millenium Edition Marketing Management", Interpreting Hendra Teguh, SE, AKT (ed, Ronny A. Rusli, SE, AKT), Jakarta.

10. Lupiyoadi, Rambat and Hamdani, A, 2006, "Service Marketing Management", Issue 2, Salemba Empat.

11. Minarti, Sri, School Management, 2011 (Managing Educational Institutions Independently), Yogyakarta, ArRuzz Media 370-371.

12. Mulyadi. 2005. Strategic Management System Based on the Balanced Scorecard. Yogyakarta, UPP AMP YKPN. 
13. Mehrdad Alipour, Ali Aghamohammadi, 2012. Journal of Applied Sciences, Engineering and Technology "A New Educational Marketing Mix: The 6ps for Private School Marketing in Iran"

14. Nawawi, Hadari. 2003. Strategic Management: Non-Profit Organizations in the Field of Government with Illustrations in the Field of Education. Yogyakarta, Gadjah Mada University Press.

15. Pelhan, Afred M 1997, "Mediating Influences on Relationship Between Markets and the Probability of Small Industrial Firms", Journal of Marketing.

16. Peter Hulte $n$ and Vladimir Vanyushyn, 2014. Edward Insight about the journal of consumer marketing "Promotion and shoppers" Swedish impulse purchases: the example of clothes.

17. Robert, B. W, 1997, Customer Value: Next Source for Competitive Advantage, Journal of Academy of Marketing Science, Vol. 25.

18. Setianto, Agus, 2004, "Analysis of Effectiveness of Market Orientation, Innovation, Service Quality and Marketing Performance Influence on Competitive Advantage", Thesis, Masters Program in Management at Diponegoro University.

19. Siagian, Sondang P. 2012. Strategic Management. Jakarta, Bumi Aksara.

20. Sidik, Ignas, 2000, "Strategic Marketing and Marketing Strategy", Journal of Management Forum Prasetya Mulya No. 72, Year 14, p. 14-19. 